\title{
EFFECTS OF TRADITIONAL STRENGTH TRAINING AND OLYMPIC WEIGHTLIFTING IN HANDBALL PLAYERS
}

\author{
EFEITOS DO TREINAMENTO DE FORÇA TRADICIONAL ELEVANTAMENTO DE PESO OLÍMPICO EM \\ JOGADORES DEHANDEBOL
}

\author{
EFECTOS DEL ENTRENAMIENTO DE FUERZA TRADICIONAL Y LEVANTAMIENTO DE PESO OLIMMICO \\ EN JUGADORES DE BALONMANO
}

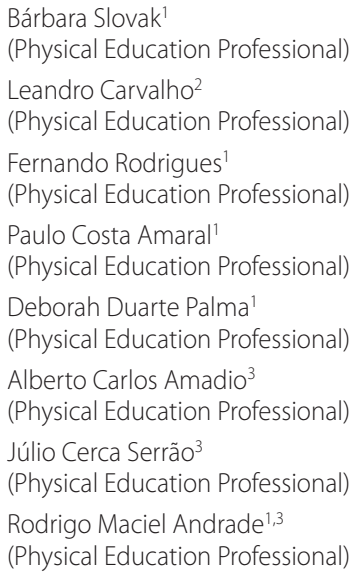

1. Universidade Anhembi Morumbi, Sport and Physical Activity Group, Sao Paulo, SP, Brazil.

2. Handebol Diadema (E.E), Fábio Eduardo Ramos Esquivel, Diadema, Sao Paulo, SP, Brazil.

3. Universidade de São Paulo, School of Physical Education and Sport, Biomechanics Laboratory, Sao Paulo, SP, Brazil.

\section{Correspondence:}

Rodrigo Maciel Andrade Universidade Anhembi Morumbi. Rua Dr. Almeida Lima, 1134, Parque da Mooca, Sao Paulo, SP, Brazil. 03164-000. rodmaciel@gmail.com

\begin{abstract}
Introduction: Olympic weightlifting has been adopted as an alternative to plyometric exercise. However, the effects of these exercises in young handball athletes is not known. Objective: To compare the effect of Olympic weightlifting training with traditional strength training on jumping, squatting and acceleration performance in young handball athletes. Ten female handball athletes were evaluated. After six weeks of regular training, the athletes underwent eight weeks of training specifically designed for the survey, with equivalence of the total volume of training and differences in the means used. The evaluations were performed after six weeks of regular training (Baseline), after four weeks of traditional strength training and after four weeks of Olympic weightlifting. Vertical Jumps with and without movement of the arms, acceleration of $10 \mathrm{~m}, 20 \mathrm{~m}$ and $30 \mathrm{~m}$, and 1RM in squatting were quantified. Results: Increases $(p<0.05)$ were observed in accelerations and squatting in the Olympic weightlifting and in squatting in the traditional strength training. Differences in coordination, time to activation of the gastrocnemius, vastus lateralis, rectus femoris, biceps femoris and gluteus maximus, peak force and power and rate of force development between the jumps and exercises used in the training are hypotheses to be considered for the different responses adaptations found in the jumps. Conclusion: The Olympic weightlifting training resulted in an increase in accelerations and strength, but not in vertical jump performance in young handball athletes. Level of Evidence I; Prognostic Studies - Investigation of the Effect of a Patient Characteristic on Disease Outcome.
\end{abstract}

Keywords: Exercise; Mechanics; Efficiency; Muscle strength; Resistance training.

\section{RESUMO}

Introdução: O levantamento olímpico de halterofilismo tem sido adotado como alternativa ao exercício pliométrico. No entanto, pouco se conhece a respeito dos efeitos desses exercícios em jovens atletas de handebol. Objetivo: Comparar o efeito do treinamento com levantamento olímpico e do treinamento de força tradicional no desempenho de salto, agachamento e aceleração em jovens atletas de handebol. Dez mulheres atletas de handebol foram avaliadas. Depois de seis semanas de treinamento regular, as atletas foram submetidas a oito semanas de treinamento especificamente projetado para a pesquisa, com equivalência do volume total de treinamento e das diferenças dos meios utilizados. As avaliações foram realizadas após seis semanas de treinamento regular (Baseline), após quatro semanas de treinamento de força tradicional e após quatro semanas de treinamento com levantamento olímpico. Foram quantificados os saltos verticais sem e com movimentação dos membros superiores, aceleração de 10, 20 e 30 m e 1 RM no agachamento. Resultados: Constatou-se aumento $(p<0,05)$ das acelerações e do agachamento no treinamento com levantamento olímpico e do agachamento no treinamento de força tradicional. Distinções na coordenação, tempo para ativação do gastrocnêmio, vasto lateral, reto femoral, bíceps femoral e glúteo máximo, pico de força e potência e taxa de desenvolvimento de força entre os saltos e exercícios utilizados nos treinamentos são hipóteses a serem consideradas para as distintas respostas adaptativas encontradas nos saltos. Conclusão: 0 treinamento com levantamento olímpico resultou em aumento da aceleração e força, mas não no desempenho do salto vertical em atletas juvenis de handebol. Nível de Evidência l; Estudos de Prognóstico - Investigação do Efeito da Característica de um Paciente no Resultado da Doença.

Descritores: Exercício; Mecânica; Eficiência; Força muscular; Treinamento de resistência.

\section{RESUMEN}

Introducción: El levantamiento olímpico de halterofilia, ha sido adoptado como alternativa al ejercicio pliométrico. Sin embargo, poco se conoce acerca de los efectos de estos ejercicios en jóvenes atletas de balonmano. Objetivo: Comparar el efecto del entrenamiento con levantamiento olímpico y del entrenamiento tradicional de fuerza en el desempeño de salto, sentadillas y aceleración en jóvenes atletas de balonmano. Se evaluaron diez atletas de balonmano del sexo femenino. Después de seis semanas de entrenamiento regular, las atletas fueron sometidas a ocho semanas de entrenamiento específicamente diseñado para la investigación, con equivalencia del volumen total de entrenamiento y de las diferencias de los medios utilizados. Las evaluaciones se realizaron después de seis semanas 
de entrenamiento regular (Baseline), después de cuatro semanas de entrenamiento tradicional de fuerza y después de cuatro semanas de entrenamiento con levantamiento olímpico. Se cuantificaron los saltos verticales sin y con movimiento de las extremidades superiores, aceleración de $10 \mathrm{~m}, 20 \mathrm{~m}$ y $30 \mathrm{~m}$ y 1 RM en las sentadillas. Resultados: Se constató aumento $(p<0,05)$ de las aceleraciones y de las sentadillas en el entrenamiento con levantamiento olímpico y en las sentadillas en el entrenamiento tradicional de fuerza. La diferencia en la coordinación, tiempo para la activación del gastrocnemio, vasto lateral, recto femoral, bíceps femoral y glúteo máximo, pico de fuerza y potencia y tasa de desarrollo de fuerza entre los saltos y ejercicios utilizados en los entrenamientos son hipótesis a ser consideradas para las distintas respuestas adaptativas encontradas en los saltos. Conclusión: El entrenamiento con levantamiento olímpico resultó en u aumento de la aceleración y fuerza, pero no en el desempeño del salto vertical en atletas juveniles de balonmano. Nivel de Evidencia l; Estudios de Pronóstico - Investigación del Efecto de la Característica de un Paciente sobre el Resultado de la Enfermedad.

Descriptores: Ejercicio; Mecánica; Eficiencia; Fuerza muscular; Entrenamiento de resistencia.

\section{INTRODUCTION}

Muscular strength is the skeletal muscle capacity to produce tension and is fundamental for the execution of motor gestures in sport. It is important to optimize muscle strength in order to improve performance.

In handball, although strength and its variants are important for passes and pitches, the development of this ability in lower limbs is fundamental, as $29.1 \%$ of the gestures are low-speed runs $\left(1.4-3 \mathrm{~m} \cdot \mathrm{s}^{-1}\right)$, $29.7 \%$ high-speed runs (3.1-5.2 $\left.\mathrm{m} \cdot \mathrm{s}^{-1}\right)$ and $10.5 \%$ sprint $\left(>5.2 \mathrm{~m} \cdot \mathrm{s}^{-1}\right) .{ }^{1}$

Different strategies and methods have been proposed to increase these moves and performance. These include traditional strength-training exercises (TST) and plyometric training (PT).

TST is based on the sequential chain of increasing strength, power, speed and consequent performance. ${ }^{2}$ PT is based on greater development of the eccentric-concentric cycle, elastic and mechanical power and reflex ${ }^{3}$ for performance improvement. Although extensive knowledge has been produced with such models, Olympic weightlifting $(\mathrm{OWL})$ has now been adopted as alternatives to TST and PT, given the expressive gains of power by elastic and reflex enhancement of the stimulated structures. ${ }^{4}$

Thus, adopting OWL allows greater transfer of adaptive responses to the sports environment, allowing the athlete to perform the characteristic movements of the sport with higher performance.

We are not aware of any studies aimed at understanding the application of OWL on functional aspects compared to TST in young handball athletes.

The objective of this study was to compare the effects of OWL and TST on muscle strength and power of lower limbs and acceleration in young handball athletes.

\section{MATERIAL AND METHODS}

Ten experienced ( $5 \pm 1$ years of practice) young female handball

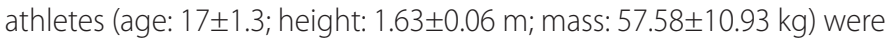
evaluated. The inclusion criteria were the following: being an athlete enrolled in Federação Paulista de Handebol and handball experience of more than three years. As an exclusion criterion, medical diagnosis or self-reported pain that could affect the study.

After signing an Informed Consent previously approved by the Research Ethics Committee (Certificate of Submission of Ethical Assessment no. 73738917.1.0000.5492, protocol no. 093878/2017), the athletes underwent eight weeks of training. (Table 1)

Preparatory Periods 1 and 2 were structured with equivalence of total training volume (sets $x$ reps $\times$ load volume per repetition) plus differences of means. (Table 2)

The athletes were tested at the beginning of Preparatory Period 1 (Baseline) and 2 (post TST), and at the end of Preparatory Period 2 (post OWL). At each moment, anthropometric measures and functional
Table 1. Organization of training stages and collection tasks.

\begin{tabular}{|c|c|c|c|}
\hline & $\begin{array}{c}\text { Preparatory period } \\
1\end{array}$ & $\begin{array}{c}\text { Preparatory period } \\
2\end{array}$ & $\begin{array}{c}\text { Competitive } \\
\text { period }\end{array}$ \\
\hline Duration & 4 weeks & 4 weeks & \\
\hline Objective & $\begin{array}{c}\text { To develop and } \\
\text { combine physical } \\
\text { and motor skills with } \\
\text { TST approaches }\end{array}$ & $\begin{array}{c}\text { To develop and } \\
\text { combine physical } \\
\text { and motor skills with } \\
\text { OWL approaches }\end{array}$ & $\begin{array}{l}\text { Achieving the best } \\
\text { results within the } \\
\text { available margin } \\
\text { of preparation }\end{array}$ \\
\hline
\end{tabular}

Table 2. Organization of training approaches and total volume in each stage.

\begin{tabular}{|c|c|c|c|c|c|c|c|c|c|c|c|c|}
\hline \multirow{2}{*}{ Approaches } & \multicolumn{3}{|c|}{ Week 1} & \multicolumn{3}{|c|}{ Week 2} & \multicolumn{3}{|c|}{ Week 3} & \multicolumn{3}{|c|}{ Week 4} \\
\hline & $S$ & R & $C$ & $S$ & $\mathbf{R}$ & $C$ & $S$ & $\mathbf{R}$ & $C$ & $S$ & $\mathbf{R}$ & $C$ \\
\hline 1 & 3 & 10 & 45 & 3 & 8 & 47 & 3 & 5 & 54 & 3 & 3 & 58 \\
\hline 2 & 3 & 8 & 24 & 3 & 6 & 28 & 4 & 5 & 32 & 4 & 3 & 33 \\
\hline 3 & 3 & 8 & 24 & 3 & 6 & 28 & 4 & 5 & 32 & 4 & 3 & 34 \\
\hline 4 & 3 & 8 & 24 & 3 & 6 & 28 & 4 & 5 & 32 & 4 & 3 & 32 \\
\hline 5 & 3 & 10 & 30 & 3 & 10 & 34 & 3 & 7 & 36 & 3 & 7 & 38 \\
\hline $\mathrm{VL}$ & \multicolumn{3}{|c|}{3978} & \multicolumn{3}{|c|}{3660} & \multicolumn{3}{|c|}{3486} & \multicolumn{3}{|c|}{2508} \\
\hline \multirow{2}{*}{ Approaches } & \multicolumn{3}{|c|}{ Week 5} & \multicolumn{3}{|c|}{ Week 6} & \multicolumn{3}{|c|}{ Week 7} & \multicolumn{3}{|c|}{ Week 8} \\
\hline & $\mathrm{S}$ & $\mathrm{R}$ & $C$ & $\mathrm{~S}$ & $\mathbf{R}$ & $\mathrm{C}$ & $S$ & $\mathbf{R}$ & $C$ & $\mathrm{~S}$ & $\mathbf{R}$ & $C$ \\
\hline 6 & 3 & 10 & 34 & 3 & 9 & 40 & 3 & 7 & 46 & 3 & 5 & 46 \\
\hline 7 & 3 & 10 & 22 & 3 & 9 & 28 & 3 & 7 & 31 & 3 & 5 & 34 \\
\hline 8 & 3 & 10 & 25 & 3 & 7 & 28 & 3 & 7 & 31 & 3 & 5 & 30 \\
\hline 9 & 3 & 10 & 26 & 3 & 7 & 30 & 3 & 7 & 32 & 3 & 5 & 32 \\
\hline 10 & 3 & 10 & 22 & 3 & 7 & 26 & 3 & 7 & 28 & 3 & 5 & 30 \\
\hline$V L$ & \multicolumn{3}{|c|}{3870} & \multicolumn{3}{|c|}{3600} & \multicolumn{3}{|c|}{3528} & \multicolumn{3}{|c|}{2580} \\
\hline
\end{tabular}

Where: 1. Squatting; 2. Earth lifting; 3. Stiff; 4. Bench press; 5 . Bent-over Row; 6 . Squatting; 7. Snatch pull; 8. Ful snatch; 9 . Second round in the throwing gesture; 10 . Bench press; $S$. number of sets performed; R. number of repetitions; C. load used; VL. total volume of the session.

tests were performed at the usual training places and times, always supervised by the team coach.

Body height and mass were measured using a stadiometer and a mechanical scale (Filizola ${ }^{\circledR}$ - Brazil), respectively. The procedures followed the standards of the International Society for Advance of Kinanthropometry. ${ }^{5}$

Estimation of maximum squatting load (1RM) was used as an indication of muscle strength of lower limbs. ${ }^{6}$ For the muscle power of lower limbs, vertical jumps (VJ), ${ }_{1}^{7}$ condition with counter-movement and free movement of the arms, and Vertical Power Jump (VPJ), ${ }_{1}^{7}$ condition with counter-movement and restriction of arm movement. The jump height was quantified by the Globus Systems ${ }^{\circledR}$ (Globus Brasil, RJ, Brazil) with 0.001 s precision.

The 30-meter test ${ }^{8}$ was used to obtain acceleration parameters. Globus Systems ${ }^{\circledR}$ (Globus Brasil, Niterói, RJ, Brazil) photoelectric cells of $0.001 \mathrm{~s}$ precision placed at approximately 1 meter height from the ground (a height that is closer to the volunteers' hip height), and after 10, 20 and 30 meters. Once the times to travel each distance were known and by applying the fundamental concepts of kinematic, the 
mean scalar velocity () and mean scalar acceleration () were calculated for each distance ( $a_{m} 10 m, a_{m} 20 m$ and $a_{m} 30 m$ ).

All athletes were trained to perform each of the maximum effort tests/ attempts and maintain their usual diet. A 24-hour interval was respected between the end of the last training session and the start of the tests.

For the tests, warm-up (10 minutes of active stretching followed by 10 minutes of submaximal velocity moves), jump tests, acceleration and maximum load for squatting were considered.

These tests were chosen because they represent the moves of handball ${ }^{9}$ and are used in the evaluations and training of the athletes evaluated.

\section{Statistical analysis}

After an exploratory analysis for outlier identification and exclusion by box-plot, ${ }^{10}$ the data normality was checked using the Shapiro-Wilk test, homoscedasticity by the Levene test, linearity by dispersion diagram and sphericity by Mauchly's test. ${ }^{11}$ Afterwards, descriptive statistics was adopted by mean and standard deviation.

Repeated-measures designs-General Linear Model, ${ }^{11}$ level of significance of $5 \%$ and Bonferroni post-hoc were used for the analyses.

Considering that, in the sample, small findings with no statistical significance may present considerable practical relevance, ${ }^{12}$ partial Eta-squared statistic (partial $\eta^{2}$ ) was quantified ${ }^{13}$ as this is appropriate in analysis of variance of repeated measures. ${ }^{11,12}$ Effect sizes were classified as small (partial $\eta^{2}$ up to 0.059), medium (between 0.059 and 0.138) and large (greater than 0.138). ${ }^{13,14}$

The Statistical Package for the Social Sciences - SPSS version 16.0 for Mac (SPSS Inc., Chicago, IL) was used.

\section{RESULTS}

Table 3 shows the descriptive values of the parameters obtained in the functional tests.

The comparative analysis of the parameters obtained in the functional tests are presented in Figure 1.

By considering the indicator parameter of 10-meter acceleration $\left(a_{m} 10 \mathrm{~m}\right)$, effect with statistical significance for training was evidenced [Wilks'lambda=0.380, $F(2.8)=6.521, p<0.05$, partial $\eta 2=0.620$, power $=1.00$ ]. Bonferroni post hoc test revealed that the post-OWL moment presented values significantly $(p<0.05)$ higher than that found at baseline and post TST, which was then classified as a large effect size (greater than 0.138). ${ }^{13,14}$

For the acceleration parameter of 20 and 30 meters $\left(a_{m} 20 \mathrm{~m}\right.$ and $a_{m} 30 m$, respectively), the same response was evidenced, effect with

Table 3. Descriptive statistics, mean (standard deviation) of the mean scalar acceleration for $10\left(\mathrm{a}_{\mathrm{m}} 10 \mathrm{~m}\right) ; 20\left(a_{\mathrm{m}} 20 \mathrm{~m}\right) 30\left(a_{\mathrm{m}} 30 \mathrm{~m}\right)$ meters, Vertical Power Jump (VPJ), Vertical Jump (VJ) and maximum strength predicted in squats (1RM), after six weeks of regular training (Baseline), after four weeks of traditional strength training (post-TST) and after four weeks of Olympic weightlifting (post-OWL).

\begin{tabular}{c|c|c|c}
\hline & Baseline & post-TST & post-OWL \\
\hline$a_{m} 10 \mathrm{~m}\left(\mathrm{~m} / \mathrm{s}^{2}\right)$ & $2.12( \pm 0.35)$ & $2.06( \pm 0.36)$ & $2.13( \pm 0.30)$ \\
\hline$a_{m} 20 \mathrm{~m}\left(\mathrm{~m} / \mathrm{s}^{2}\right)$ & $1.45( \pm 0.28)$ & $1.43( \pm 0.21)$ & $1.61( \pm 0.22)$ \\
\hline$a_{m} 30 \mathrm{~m}\left(\mathrm{~m} / \mathrm{s}^{2}\right)$ & $1.12( \pm 0.13)$ & $1.13( \pm 0.16)$ & $1.19( \pm 0.17)$ \\
\hline $\operatorname{VPJ}(\mathrm{m})$ & $0.29( \pm 0.05)$ & $0.28( \pm 0.04)$ & $0.28( \pm 0.05)$ \\
\hline $\operatorname{VJ}(\mathrm{m})$ & $0.34( \pm 0.04)$ & $0.32( \pm 0.04)$ & $0.33( \pm 0.05)$ \\
\hline 1 RM $(\mathrm{kg})$ & $77.02( \pm 5.77)$ & $113.79( \pm 7.85)$ & $143.47( \pm 2.09)$ \\
\hline
\end{tabular}

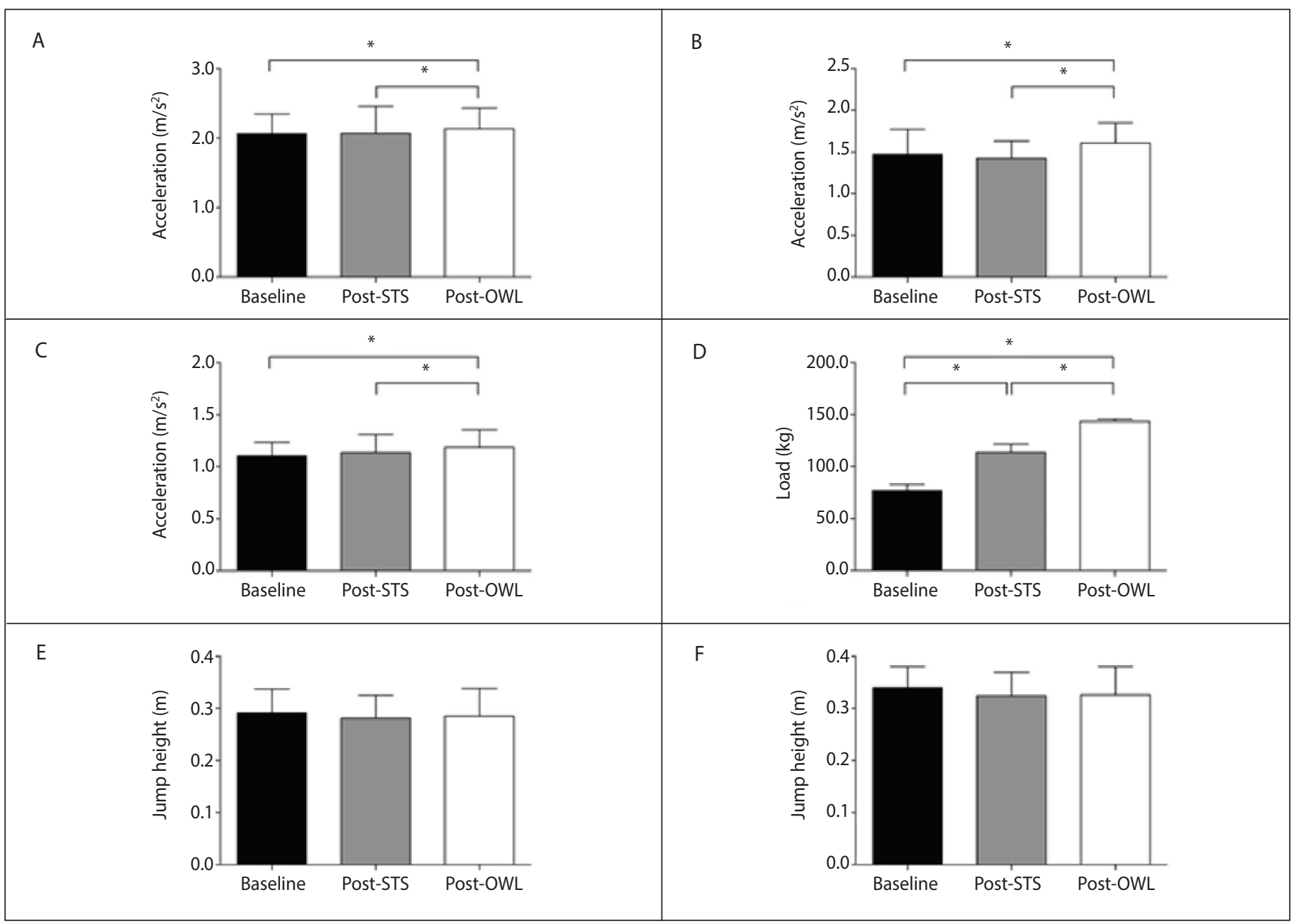

Figure 1. Comparative analysis of the mean scalar acceleration parameters for 10 (am10m - A); 20 (am20m - B) 30 (am30m - C) meters, maximum strength predicted in squats (1RM - D), Vertical Power Jump (VPJ - E) and Vertical Jump (VJ - F), after six weeks of regular training (Baseline), after four weeks of traditional strength training (post-TST) and after four weeks of Olympic weightlifting (post-OWL). 
statistical significance of training [Wilks'lambda $=0.303, F(2.8)=0.303$, $p<0.05$, partial $\eta^{2}=0.697$, power $=0.891$ and Wilks' lambda $=0.465, F$ $(2.8)=4.597, p<0.05$, partial $\eta^{2}=0.535$, power $=0.602$, respectively]. Bonferroni post hoc test revealed that the post-OWL moment presented values significantly ( $p<0.05$ ) higher than that found at baseline and post-TST, with effect sizes classified as large (greater than 0.138) for both parameters. ${ }^{13,14}$

Considering the maximum predicted squatting load (1RM), the analysis of variance reported effect with statistical significance of training [Wilks' lambda $<0.001, F(2.8)=8863.265, p<0.05$, partial $\eta^{2}=1.00$, power $=1.00]$ and Bonferroni post-hoc test revealed that the post-TST moment presented values significantly $(p<0.05)$ lower than that found at baseline and post-TST presented values significantly $(p<0.05)$ lower than that found at post-OWL and large effect sizes (greater than 0.138). ${ }^{13,14}$

For the Vertical Power Jump and Vertical Jump tests, the training effect did not present values with statistical significance [Wilks' lamb$\mathrm{da}=0.940, \mathrm{~F}(2.8)=0.257, \mathrm{p}<0.05$, partial $\eta^{2}=0.059$, power $=0.078$ and Wilks lambda $=0.818, F(2.8)=0.891, p<0.05$, partial $\eta^{2}=0.018$, power $=0.154$, respectively], with small effect size (smaller than 0.059). ${ }^{13,14}$

\section{DISCUSSION}

The objective of this study was to compare the possible effects of strength training using typical Olympic weightlifting (OWL) approaches and traditional strength training (TST) in functional performance in acceleration in 10,20 and 30 meters in squatting and vertical jump tests.

As a result, the comparative analysis, with respect to acceleration from 0 to 10 meters, 0 to 20 meters and 0 to 30 meters, there was improved performance at post-OWL compared to baseline and TST. Identical responses were found at the maximum strength predicted in squatting.

Although it was not the focus of this study to investigate the relationship between the parameters analyzed, but the dynamics of modifying the parameters after application of different means of training, it can be considered that increased acceleration can be explained by the increased maximum strength predicted.

This condition is consistent with studies that found significant correlations between acceleration in the distance of five meters and the maximum strength produced in squatting $(r=0.66){ }_{1}^{15}$ and between the maximum strength produced in squatting and the speed produced in the first three steps $(r=0.58)$ and the speed produced at a distance of five meters ( $r=0.66)$, and between the maximum strength produced in squatting and the time to travel the distance of 10 meters $(r=-0.94) .{ }^{16}$ This is similar to the conditions reported in football athletes ${ }^{17}$ and in basketball athletes. ${ }^{18}$

The mechanical basis for such findings is on the study by Andrade, ${ }^{19}$ who investigated the performance of a sprint and the parameters linked to the performance of the task. In particular, the strength applied to the ground during the sprint showed a large increment in the first five meters, followed by a short phase of less oscillation between 5 and 10 meters, and a new incremental phase between 10 and 20 meters, with less oscillation from this until the 80 meter-run was completed. Also, the percentage variations of each partial compared to the immediately preceding one indicate significant percentage changes between 2,5 and five meters, followed by decreases of 5 to $10 \%$ until 20 meters, after which, despite parameter modulations, there is no virtually linear behavior smaller than $5 \%$ is most cases.

Andrade ${ }^{19}$ also argues that the magnitude of such strength depends on the relationship between the parameters of contact time () and flight time (). Thus, the behavior of the strength applied to the ground during the sprint can be explained by the dynamics of the parameters with, in summary, a major reduction in the first 10 meters followed by a lower oscillation; and an increase in the first 10 meters of test, followed by a smaller increase until 30 meters, approximately, and a phase of smaller oscillation.

Thus, the quantification of the strength applied to the ground during the sprint can be considered as illustrative of the dynamics of the relationship between the parameters e. In this scenario, an expressive increase is expected at the beginning of the high speed and short duration run, followed by less substantial increments and lower oscillation of these values.

An inverse reasoning of these dynamics justifies a condition in which the greater the strength applied on the ground during the sprint the easier body inertia is overcome. ${ }^{20}$ The faster is reduced and is increased, ${ }^{20}$, thus demonstrating convergence in the dynamics of the parameters of strength applied to the ground during the sprint and speed in the short-duration and high-speed run, ratifying the postulate as to the need to produce considerable strength on short-range accelerations. ${ }^{21}$

With regard to the acceleration from 0 to 10 meters, 0 to 20 meters and from 0 to 30 meters, better performance was observed post-OWL compared to baseline and post-TST, considering the functional jump test. Comparative analysis showed that both training strategies resulted in adaptations with differences with no statistical significance between the baseline, post-TST and post-OWL phases.

These results are consistent with the observation that $\mathrm{OWL}$ is an effective training approach for vertical jump height increase. ${ }^{22}$

We believe that two possible phenomena can explain the distinctions of results found between this study and the literature.

The first phenomenon refers to the fact that in all cited articles, the adaptive responses induced by training in men were considered. Considering that females present 1) lower muscle volume ${ }^{23}$ and strength, ${ }^{24}$; 2) distinct contractile property of the skeletal muscle tissue due to differences in muscle fiber compositions; 3 ) greater fatigue resistance of the skeletal muscle tissue, 25 ) less acute mechanical response of load bearing in the tendon tissue, ${ }^{26}$ and 5) chronically, lower frequency of collagen synthesis in the tendon tissue, 25 it must be considered that these distinctions may influence the dynamics of adaptation to training, which could be reflected in the absence of specific modification to the jump task.

This condition is corroborated by the findings of Ayers, DeBeliso, Sevene and Adams, ${ }^{27}$ who studied 23 volleyball and softball athletes undergoing TST and OWL and found similar changes in vertical jump height after both interventions.

The second phenomenon worthy of note relates to the mechanical distinctions found between the means of training used and the vertical jump gesture analyzed.

This reasoning is based on the distinction in the extensor coordinative pattern of the ankle, knee and hip joints of the ascending phase between the power clean and the vertical jump. ${ }^{28}$ These different kinematic patterns are supported by muscle activation data that demonstrated significant differences $(p<0.05)$ in time related to peak activation of the gastrocnemius, vastus lateralis, rectus femoris, biceps femoris and gluteus medius muscles, in the significant differences in maximum level of rectus femoris and biceps femoris activation, and in the significant differences in the patterns of activation/deactivation of the vastus medialis and rectus femoris. Besides, significant differences between vertical jump and power clean in terms of peak power, rate of strength development and peak power were also reported..$^{28}$

Thus, the possibility of the biological distinctions found between men and women may interfere in a different way with the mechanical distinctions presented between Olympic weight lifting exercises and vertical jump.

Finally, and considering the hypothesis that adaptive responses in jumps are task-dependent ${ }^{19}$ and vertical jumps from a standstill condition are rare in a handball match, coaches and physical trainers should reconsider the need to assign vertical jumping tasks in handball athletes. 


\section{CONCLUSION}

Based on the results presented, the OWL intervention presents significantly better performance results in acceleration tasks up to the distance of 30 meters and squatting in young female handball athletes.

However, the functional vertical jumping test did not present any significant results in the sample, due to factors such as divergence of biomechanical movements and biological factors.

\section{ACKNOWLEDGEMENTS}

The authors acknowledge the financial support of Universidade Anhembi Morumbi, an institution associated with the publication, as well as the technical staff and athletes for their cooperation and availability.

All authors declare no potential conflict of interest related to this article

AUTHORS' CONTRIBUTIONS: Each author made significant individual contributions to this manuscript. BS (0000-0002-7764-9241)*: contributed substantially to the conception of the work, acquisition of the data, and writing the manuscript; LC (0000-0002-2172-0520*: contributed substantially to the conception of the manuscript and acquisition of the data; FR (0000-0001-7102-5297)*, PCA (0000-0002-5594-3861)*, DDP (0000-0003-3001-0237)*, ACA (0000-0002-2527-2163)* and JCS (0000-0002-3646-3387)*: contributed substantially to writing the manuscript and critical review of its intellectual content; RMA (0000-0002-4816-5635): contributed substantially to the design, acquisition, analysis and interpretation of the data, and writing the manuscript. All authors approved the final version of the manuscript. *ORCID (Open Researcher and Contributor ID).

\section{REFERENCES}

1. Manchado C, Pers J, Navarro F, Han A, Sung E, Platen P. Time-motion analysis in womn's team handball: importance of aerobic performance. J Hum Sport Exerc. 2013;8(2):376-90.

2. Ortega-Becerra M, Pareja-Blanco F, Jiménez-Reyes P, Cuadrado-Peñafiel V, González-Badillo JJ. Determinant factors of physical performance and specific $t$ in handball players of different ages. $J$ Strength Cond Res. 2018;32(6):1778-86.

3. Bracic M, Supej M, Matjacic Z. Dependence of human maximum vertical counter-movement jump height on activation sequence of the biarticular muscles. Br J Sports Med. 2011;45(6):538-9.

4. 4. Cohen M, Abdalla RJ. Lesões nos esportes: diagnóstico, prevenção e tratamento. Rio de Janeiro: Revinter; 2003.

5. Norton K, Whittingham N, Carter L, Kerr D, Gore C, Marfell-Jones M. Técnicas de medição em antropometria. In: Norton K, Olds T, (eds). Albernaz NMFd, trans. Antropométrica: um livro sobre medidas corporais para o esporte e cursos da área da saúde. Porto Alegre: Artmed; 2005: p. 41-87.

6. Kravitz L, Akalan C, Nowicki K, Kinzey SJ. Prediction of 1 repetition maximum in high-school power lifters. J Strength Cond Res. 2003;17(1):167-72.

7. Johnson BL, Nelson JK. The Measurement of Power. In: Johnson BL, Nelson JK, (eds). Practical measurements for evaluation in physical education. 2nd ed. Minneapolis, Minnesota: Burgess Publishing Company; 1974: p.166-83.

8. Coelho DB, Coelho LG, Braga ML, Paolucci A, Cabido CE, Ferreira Jr. JB, et al. Correlação entre o desempenho de jogadores de futebol no teste de sprint de 30m e no teste de salto vertical. Motriz. 2011;17(1):63-70.

9. Chelly MS, Hermassi S, Aouadi R, Khalifa R, Van den Tillaar R, Chamari K, et al. Match analysis of elite adolescent team handball players. J Strength Cond Res. 2011;25(9):2410-7.

10. Hair Jr. JF, Black WC, Babin BJ, Anderson RE. Multivariate data analysis. 7th ed. Bergen County, New Jersey: Prentice Hall; 2009.

11. Field A. Discovering statistics using SPSS. 3th ed. Thousand Oaks, California: Sage Publications Ltd; 2009.

12. Levine TR, Hullett CR. Eta squared, partial eta squared, and misreporting of effect size in communication research. H Com Res. 2002;28(4):612-25.

13. Kotrlik JW, Williams HA. The incorporation of effect size in information technology, learning, and performance research. ITLPJ. 2003;21(1):1-7.

14. Cohen J. Statistical power analysis for the behavioral sciences. 2nd ed, Hillsdale, New Jersey: Lawrence Earlbaum Associates; 1988.

15. Chelly MS, Cherif N, Amar MB, Hermassi S, Fathloun M, Bouhlel E, et al. Relationships of peak leg power, 1 maximal repetition half back squat, and leg muscle volume to 5-m sprint performance of junior soccer players. J Strength Cond Res. 2010;24(1):266-71.

16. Wisloff U, Castagna C, Helgerud J, Jones R, Hoff J. Strong correlation of maximal squat strength with sprint performance and vertical jump height in elite soccer players. Br J Sports Med. 2004;38(3):285-8.

17. McBride JM, Blow D, Kirby TJ, Haines TL, Dayne AM, Triplett NT. Relationship between maximal squat strength and five, ten, and forty yard sprint times. J Strength Cond Res. 2009;23(6):1633-6.

18. Chaouachi A, Brughelli M, Chamari K, Levin GT, Ben Abdelkrim N, Laurencelle L, et al. Lower limb maximal dynamic strength and agility determinants in elite basketball players. J Strength Cond Res. 2009;23(5):1570-7.

19. Andrade RM. Corridas de alta velocidade e curta duração: uma abordagem biomecânica para o entendimento dos fatores determinantes de desempenho [Tese]. São Paulo: Escola de Educação Física e Esporte, Universidade de São Paulo; 2015.

20. Comfort P, Bullock N, Pearson SJ. A comparison of maximal squat strength and 5-, 10-, and 20-meter sprint times, in athletes and recreationally trained men. J Strength Cond Res. 2012;26(4):937-40.

21. Harris NK, Cronin JB, Hopkins WG, Hansen KT. Relationship between sprint times and the strength/ power outputs of a machine squat jump. J Strength Cond Res. 2008;22(3):691-8.

22. Berton R, Lixandrao ME, Pinto e Silva CM, Tricoli V. Effects of weightlifting exercise, traditional resistance and plyometric training on countermovement jump performance: a meta-analysis. $J$ Sports Sci. 2018;36(18):2038-44.

23. Padua DA, Carcia CR, Arnold BL, Granata KP. Gender differences in leg stiffness and stiffness recruitment strategy during two-legged hopping. J Mot Behav. 2005;37(2):111-25.

24. Cheuvront SN, Carter R, Deruisseau KC, Moffatt RJ. Running performance differences between men and women:an update. Sports Med. 2005;35(12):1017-24.

25. Wust RC, Morse Cl, de Haan A, Jones DA, Degens H. Sex differences in contractile properties and fatigue resistance of human skeletal muscle. Exp Physiol. 2008;93(7):843-50.

26. Magnusson SP, Hansen M, Langberg H, Miller B, Haraldsson B, Westh EK, et al. The adaptability of tendon to loading differs in men and women. Int J Exp Pathol. 2007;88(4):237-40.

27. Ayers JL, DeBeliso M, Sevene TG, Adams KJ. Hang cleans and hang snatches produce similar improvements in female collegiate athletes. Biol Sport. 2016;33(3):251-6.

28. MacKenzie SJ, Lavers RJ, Wallace BB. A biomechanical comparison of the vertical jump, power clean, and jump squat. J Sports Sci. 2014;32(16):1576-85 